\title{
The Role of the Supervision in Preparing a Professional Physical Education Teacher in the Industrial Revolution Era 4.0
}

\author{
Sunarno Basuki \\ Health and Recreation Physical Education Department \\ Teacher Training and Education Faculty \\ Universitas Lambung Mangkurat \\ sunarnobasuki@gmail.com
}

\begin{abstract}
The world of education is directly influenced by the industrial revolution 4.0. How to teach the teacher and the style of student learning have relied on the internet. They look for information sources with broad access without being restricted by region and time. If the world of education is not responsive to this problem, then our education will also be stagnant. The purpose of this study was to describe the role of supervision in preparing professional teachers in the era of industrial revolution 4.0. The research method was descriptive by gathering information from the review literature. The proper use of Information Technology and Communication in physical education helps develop specific skills among students, including collaborative work, independence, critical ability, responsibility, and information seeking. Things that must be considered in the preparation of teachers in the industrial revolution 4.0 era, namely: pre-profession or college period, school capacity, the condition of students. Educational supervision is needed to help teachers have the competencies needed to determine, choose and apply technology in the learning process at the school. Academic and managerial supervision will help schools understand the real conditions for meeting the needs of teachers and students. So it is necessary to supervise education to help meet the demands of the 4.0 industrial revolution.
\end{abstract}

Keywords-industrial revolution 4.0; supervision; physical education teacher

\section{INTRODUCTION}

Reference [1] delivered the four stages of the industrial revolution until the 4th generation. The first industrial revolution occurred in the late 18th century, which was marked by the discovery of mechanical looms in 1784 that used hydropower and steam. The industry that initially relied on human and animal power was eventually replaced by the machine. As a result, many people were unemployed, and the production capacity is multiplied.

The second revolution occurred in the early 20th century marked by the division of labor and mass production. The first production line involved abattoirs in Cincinnati, United States, in 1870. The third industrial revolution in the early 1970s was marked by the emergence of the use of electronic technology and information to automate production. Specially, it was characterized by the appearance of the first programmable logic controller (PLC), the modem 084-969. This computerbased automation system made industrial machines no longer controlled by humans. As a result, production costs were cheaper. The fourth revolution, currently (2018), is characterized by a cyber-physical system. At present the industry is beginning to touch the virtual world, in the form of human, machine and data connectivity, everything is everywhere. This term is known as the internet of things (IoT).

The development of this industrial revolution has made it easier for human tasks and work, very much dependent on the technology itself, and requires special skills to master the technology. Also, in the fourth revolution, technology not only becomes the domain of the industrial world but is also used by various community groups, including in the world of education. The use of the internet, as a milestone in the industrial revolution 4.0 has started since the $90 \mathrm{~s}$, but today the world sees its impact so broad and significant in human life. This is the industrial revolution that is being felt.

The first industrial revolution gave birth to history when human and animal power was replaced by the emergence of steam engines in the 18th century. This revolution is recorded by history to change the economy dramatically. Next, the second generation industrial revolution was marked by the emergence of electric power plants that triggered the emergence of telephone, cars, airplanes, and others that significantly changed the face of the world. Then the third industrial revolution was marked by the emergence of the computer, internet and digital technologies that transformed not only the industrial world but also the primary culture and habits of the generation.

This fourth generation industrial revolution is marked by the emergence of super computers or Artificial Intelligence. There will be a lot of work lost because it will be replaced by a robot or artificial intelligence. However, this is also an opportunity because many new fields of work are emerging. The challenge of education in the future is how to prepare human resources that will not be replaced by the machine.

The impact of using this super-intelligent computer influences people's behavior. Especially at this time, in the 
form of mobile phones, smart technology can be run. Most of our people already know and use smartphones with various applications that continue to grow. The world of education is directly influenced by this industrial revolution. How to teach the teacher, the style of learning students already rely on the internet. They are looking for sources of information with broad access without being limited by region and time. If the education world is not responsive to this problem, then our education will also stagnate. Inevitably we have to anticipate this dramatic change. We can no longer rely on and be faithful to the system of learning with lecture methods. The learning service system with e-learning is being promoted, and it is also possible that the face-to-face system will be lost.

Providing superior human resources is the most essential thing in the face of the Industrial Revolution 4.0. The quality of education must also be improved. The presence of an innovation, of course, has pros and cons depending on the perspective in interpreting it. The use of the technology industry such as the internet in the learning process is not new in developing countries. In connection with this, the problem of teachers is fundamental in facing the challenges of the industrial revolution 4.0. To be able to face all these challenges, an essential requirement that must be met is how to prepare qualified teacher qualifications and competencies. The reason is, in the industrial revolution era 4.0 the teaching profession is increasingly competitive.

The professionalism of teachers who can adapt to the industrial revolution 4.0 is the hope of all parties. However, to make it happen the role of another party is needed, namely the supervisor in realizing it. Supervision is seen as an activity to help teachers improve their abilities. Teaching supervision is a series of activities to help teachers develop their ability to manage the teaching and learning process to achieve learning goals [2]. The essence of supervision is not to assess teacher performance in leading the teaching and learning process, but to help teachers develop their abilities. Evaluation of teachers is carried out to dig up data that is followed up with guidance and development of teacher abilities. Supervision is expected to help teachers prepare themselves to have competencies by the demands of the industrial revolution era 4.0.

\section{METHOD}

This article is a literature review. In the most rigorous form of research, educators base this review mainly on research reported in journal articles [3].

\section{Result AND Discussion}

\section{A. Physical Education Teacher Description}

Until now, there are still many people who see that being a physical education teacher is very easy, just by having children go to the field, providing soccer balls for men and volleyball for women. While the teacher is sitting around while watching the activities of his students, this kind of picture is still in the minds of many people. If we understand the task of the teacher, then there are a lot of demands that must be possessed by the teacher.
Physical Education is education that uses physical activity as a medium to achieve learning goals. Physical education is defined as the process of education through physical activity or the process of educating children through physical activity. The core understanding is to educate children. What distinguishes it from other subjects is that the tools or media used are human movements, humans who move consciously.

The movement is consciously designed by the teacher and given in the right situation so that it can stimulate the growth and development of students. This provides an opportunity for children to learn various activities that foster while developing children's potential, both in physical, mental, social, emotional and moral aspects. In short, physical education aims to develop the potential of each child as high as possible. The achievement of these goals stems from the planning of a motion experience that is appropriate to the characteristics of the child. In this case, the teacher should have adequate general basic abilities that include mastery and organization of the material to be taught and mastery of the delivery method and its assessment.

In detail, the competencies that should be possessed by a training teacher are as follow:

- Having the ability to identify children's characteristics of physical growth, mental development, social and emotional development by the growth phases.

- Having the ability to arouse and provide opportunities for children to be active and creative in the process of learning physical education, and able to develop the potential abilities and motor skills of children.

- Having the ability to provide guidance and child development in the learning process to achieve physical education goals.

- Having the ability to plan, implement, control and assess and correct the physical education learning process.

- Having the ability to create, develop, and utilize existing environmental factors in achieving physical education goals.

Some study results provide a less encouraging picture of physical education teachers. Reference [4] examined the creativity of Physical Education teachers using facilities and infrastructure in Kulonprogo Regency, Jogjakarta. The results of his study submitted several conclusions. First, the teacher's ability to create and implement ideas to solve problems through modification of Physical Education facilities and infrastructure were very lacking, and the teacher's attitude towards the progress of Physical Education learning was insufficient. It could be an influence because the teacher looks indifferent to the students 'abilities and does not care about their students' ability to do activities. Second, the ability of teachers to create and implement ideas to solve problems of modification of Physical Education facilities and infrastructure were still low. This condition is indeed very alarming, mainly as it is associated with the 4.0 industrial revolution that relies heavily on technology. How do they deal with the world of education that is heavily influenced by technology, while they lack creativity and the ability to use facilities and infrastructure? 
Reference [5] mapped the profile of Physical Education teachers to Elementary Schools in the city of Bengkulu. The results of their research showed that elementary school physical and health education teachers in Bengkulu City had not comprehensively comprehended the competence of education personnel. From the results of study that had been carried out, not all teachers had four competencies as professional educators, namely; 1) pedagogical competence, 2) personal competence, 3) professional competence, and 4) social competence. This makes homework for the local government to be able to improve the quality of teaching staff so that the competence of teaching staff is truly by the mandate of Law No. 20 of 2003 concerning the National Education System of the Republic of Indonesia. The law states that educators must have professionalism.

The teaching profession must have four competencies mentioned above. So, if the teacher does not have these four competencies, the teacher is not yet worthy of holding the teaching profession, just merely teacher. The results of this study indicate that the condition of physical education teacher competence at the elementary school level in the city of Bengkulu is still not satisfactory. This can be seen from pedagogical competence, where there are $50.1 \%$ of teachers who are competent and $40.9 \%$ of teachers do not have pedagogical competence. Personality competence shows $95.5 \%$ of competent teachers and $4.5 \%$ of teachers are not competent. Professional competence shows $46.6 \%$ of competent teachers, and $53.4 \%$ of teachers do not have professional competence. This is one of the weaknesses of physical education teachers who lack innovation in learning, and innovation in learning is one form of professional competence. Social competence shows that $65.92 \%$ of teachers are competent, but there are still $34.02 \%$ of teachers who have not been able to master social competence, whereas social skill is needed in the teaching and learning process and the daily life of a teacher.

One of the abilities required of Physical Education teachers is to make classroom action research. Reference [6] conveyed the results of her study on this ability to elementary school physical education teachers throughout Banda Aceh. First, Health And Recreation Physical Teachers in Public Schools in Banda Aceh City had not been able to make Class Action Research reports properly. This was due to the difficulty in using computers so that it had an impact on the teacher's lack of ability to use computers. Secondly, Health And Recreation Physical Teachers in Public Schools in Banda Aceh City received inadequate training related to the preparation of classroom action research reports. This caused the teacher to need typing services on computer rentals. Therefore they hope to the relevant agencies for the workshop in the context of preparing class action research reports. This research report illustrates that teachers are not ready to use advanced technology. Of course, this will make it difficult to invite teachers to face the 4.0 industrial revolution that has been based on digital, intelligent computers and information technology.

\section{B. Challenges Of Physical Education In The Industrial Revolution Era 4.0}

Industry 4.0, as a phase of the technological revolution, changes the way human activities work in the scale, scope, complexity, and transformation of previous life experiences. Information, video and intelligent computer technology have been used in the field of education. In some countries, this has been applied to the field of physical education. For example, digital devices in measuring heart rate in exercise have been used. Similarly, the use of video before the physical education learning process can also be applied by teachers in serving their students.

In the context of sports science, the use of technology has changed and has enriched the teaching and learning process, methods, assessment instruments and data archiving regarding student activities and physical appearance. Physical education has changed and expanded but requires ongoing competency updates and teacher training. Teachers are expected to be able to use tools and applications in physical education as well as by the Internet, promoting conscious physical activities, supporting the expansion of the educative effects of interventions in physical activity and exercise even after periods of activity (self-assessment of performance, level of physical activity and related behavior). Teachers are expected to improve the effectiveness and quality of the education process from planning to implementing assessments and interventions between students, parents, principals, coworkers, and researchers.

Technology, especially in recent years, has enriched education, expanded content, tools, methodology and changed the relationship between subjects, teachers, and students. Rapid development in electronic technology has made an essential effect on the education system in the world. The use of technology is an essential effect of mediation between science and students, helping to change the way learning, developing intrinsic motivation and metacognition.

Many applications regarding physical and fitness activities are available and easily accessible. At present, the application of various technologies by students and teachers requires new competencies. Students must demonstrate motor competence and use technology, especially through an independent learning process. It is very important to learn to manage the organization of joint activities with the use of different equipment. Teachers, on the other hand, need to be more aware of teaching styles and strategies and must always support the use of technological applications in physical education [7]. Reference [8] showed that teachers had a positive attitude but were still limited in the use of technology. The limitations of the use of technology were influenced by the school budget, the number of large classes/groups and the process of permanent teacher training. Physical educators can only apply technology in teaching if training is offered and appropriate financial resources are available. In this case, the challenge is a school policy, regarding the budget and awareness of the importance of using technology in the learning process.

Also, the next issue is the competence of the teacher itself. The previous description clearly shows that there are demands for changes in competencies that are compatible with 
technological developments. There are at least five teacher qualifications and competencies needed in the 4.0 era. They include based on reference [9]:

- Educational competence, the competence of educating / internet-based learning of thing as an essential skill in this era;

- Competence for technological commercialization, the competence to bring students to have an entrepreneurial attitude (entrepreneurship) with technology for students' innovative work;

- Competence in globalization, a world without insulation, not stuttering about various cultures, hybrid competencies, namely global competence and excellence in solving national problems;

- Competence in future strategies, the world is easy to change and run fast, so it is necessary to have the competence to predict exactly what will happen in the future and its strategy, by way of joint-lecture, jointresearch, joint-resources, staff mobility, and rotation, understanding the direction of the SDGs, and so forth.

- Counselor competence, remembering that in the future, the problem of children is not in the difficulty of understanding teaching material, but more related to psychological problems, stress due to the pressure of increasingly complex and severe conditions.

Physical education gets a significant contribution from technology to improve the quality of teaching and learning. Even so, technology, equipment, even the most sophisticated may not replace physical activity from the basis of physical education. Teaching methodology, technology is a tool that enhances physical education by applying the educational learning process. Other contributions include the use of social media for the interaction between different subjects and the value of sports experience carried out in different socio-cultural contexts. The quality of physical education involves the integration of the environment, activities, methods, and tools and not separation or alienating them from the physical activity itself.

Some educational challenges in the next few years will be more about personalizing learning, collaborative work, changing teacher roles, and creating authentic learning opportunities. Appropriate use of ICT (Information and Communication Technology) in physical education helps develop specific skills among students, including collaborative work, independence, critical ability, responsibility, and information seeking. The incorporation of ICT in physical education has encouraged sports activities. There have been many examples of how the use of ICT in physical education can stimulate the practice of physical activity among students. When social networks are used correctly, they become powerful tools for promoting a healthy lifestyle among adolescents [10]. \#Quesepegue project in reference [11] uses Twitter to enliven the break with healthy physical activity. Finally, the use of m-learning or mobile learning in reference [10] paves the way for new forms of teaching and learning, which are useful and functional, and facilitate interaction, collaboration, increase knowledge and a combination of formal and informal learning. In this way, education tends to become more personal and extends beyond the walls of the classroom.

The study conducted by reference [12] shows that technology-based approaches to learning physical education can be significantly involved. Such a technology approach can improve the quality of assessment, as happened in research conducted as a direct result of video analysis. This approach supports teacher cognition and learning in creating a quality learning environment where students can work productively with a clear focus on learning. The results of this study confirm that technology can help the learning process of physical education in schools. Thus the mastery of technology itself is a challenge for teachers who must be mastered to make technology support the learning process of physical education in schools.

Reference [13] mentions there are six technological challenges in the world of education, namely:

- Challenges of professional development. The key among all challenges is the lack of adequate and sustainable professional development for teachers who are asked to integrate new technology into their classrooms. Often, when schools mandate the use of certain technologies, teachers are left without tools to effectively integrate new abilities into their teaching methods. Finally, new investments are underutilized, not used at all, or used in ways that mimic the old process rather than new process innovations that may be more attractive to students.

- Challenge of rejection. Rejection of technology comes in various forms, but one of the main resistance challenges identified in the report is "comfort with the status quo." According to researchers, teachers and school leaders often see technological experiments beyond the scope of their job descriptions.

- Challenges of the learning model competition. Learning models that use online sources often face new models or even deal with conventional models. Teachers are often still comfortable in traditional and conventional models.

- Challenges of informal learning. Regarding challenge 3, rigid learning and learning models will fail to encourage students to experiment and engage in informal learning. Opportunities for such informal learning can be found in non-traditional classroom models, which allow for the mixing of formal and informal education.

- Challenges of personalized learning failure. There is a gap between the vision of delivering personal instructions and available technology. There needs to be technology that helps teachers provide more personalized learning but often fails because there are no adequate tools.

- Challenge of failure to use technology to provide an effective formative assessment. Assessment is an important driver in educational practice and change. There is still a gap between appraisal and the demands of new skills implemented in education; schools do not 
always make the adjustments needed in assessment practices as a consequence of this change - a simple application of digital media tools, such as a webcam that allows peer observation that does not interfere with work.

\section{Preparing Teacher's Education In The Industrial Revolution Era 4.0}

The development of information technology that is currently using smart computers or smartphones as a sign of the 4.0 industrial revolution cannot be stopped. Even some of the studies described previously cannot be separated from the world of education, including physical education. Various challenges emerged in the face of this industrial revolution for physical education teachers. The key factor is the readiness of the physical education teacher itself in the face of this revolution. Readiness in the form of competency skills is necessary. Without this skill, they do not give any answers to the changes that are happening, and they even seem to reject the use of advanced technology in helping in the teaching and learning process.

To prepare physical education teachers in the 4.0 industrial revolution era, the authors propose the concept described as follows:

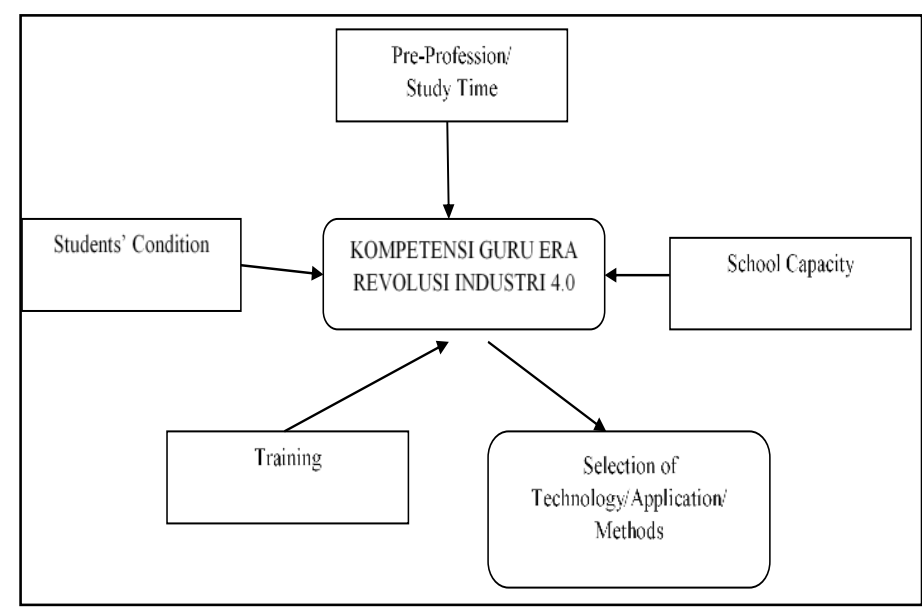

Fig. 1. Strategy for Preparing Physical Education Teachers in the Industrial Revolution Era 4.0

In the picture above, some main points need to be discussed. There are at least four factors that determine the success of the physical education teacher preparation program in the industrial revolution 4.0, namely: pre-profession or college, school capacity, student condition. After the teacher is ready to answer the challenges of the industrial revolution 4.0, he or she is expected to be able to choose the method of learning, the right technology for learning physical education in school.

\section{Pre-Profession}

If we are asked which one is better, train the teacher when he is a teacher, or before becoming a teacher, of course, we will choose before becoming a teacher. This is because before a person is employed as a teacher, he should have fulfilled various requirements as a teacher. Being a physical education teacher is not easy. He not only teaches sports but also teaches a healthy lifestyle, trains students to excel in certain sports fields and so on. Therefore an adequate provision as a teacher becomes a fundamental requirement for the preparation of teachers who master technology.

Currently, students are familiar with more sophisticated technology. They are familiar with smartphones like computers that can be carried everywhere. But unfortunately, this does not become a special program during college. Lessons in college still do not train them to use technology in learning. In other words, training in college regarding technology that is developing in the learning process will facilitate and provide better Physical Education teachers.

In this case, of course, the readiness of the teacher education institution is needed to prepare students who are already familiar with advanced technology. The curriculum in universities has included elements of technological competence in learning. Finally, the use of technology-based learning media does not become a separate department but must be in every teacher's program in various majors. Both physical education majors, language majors and so on, the need for information technology is a necessary capability that must be possessed by prospective teacher students. The success of this program in the future will reduce the burden on schools or government in training. There will be fewer additional competencies needed, compared to teachers who are not trained in technology when they are students.

\section{E. School Capacity}

As previously mentioned, often the readiness of teachers to use technology is not supported by school capacity, such as concerning budget. The technology is not cheap, and that means it needs a special budget to prepare it. While on the other hand, schools, especially public schools, budgeting is very dependent on government policies. Technology preparation for teachers cannot be easily fulfilled.

Also, awareness of the importance of technology by school policyholders is crucial. If the public school policyholder is the government, then private schools are leaders of foundations or managers. Not all of these policyholders have the same vision for technological needs. They may see a need but are considered not urgent. There are those who strive earnestly in providing technology facilities for teachers and students, and various ways are pursued, for example, borrowing funds for the provision of these technologies.

\section{F. Students' Condition}

A teacher in teaching certainly needs to know the condition of his students. Indeed, currently the majority of school students, junior and senior high school, even elementary school, are familiar with smartphones with various applications that have the same ability as computers. But of course, not all students in Indonesia have this background. Understanding student conditions are essential in determining the need for technology that will be used in the learning process. In connection with school policy, the problem of student conditions can be a very important consideration. If many 
students already use technology, are familiar with the technology, of course, the use of technology in the process of learning physical education becomes very important and needed. But if the condition of students still does not have such conditions, then the use of technology can be limited to certain things that can indeed help students learn in school.

School policies in the application of technology cannot be forced on the students or families. Student circumstances and school capacity are interconnected. Technological developments cannot be delayed or inhibited. Although students do not know the technology in depth, the school has the responsibility to provide supplies by introducing students to good and useful technology. Because when they graduate and continue at a higher level, they are not surprised, not left behind. At a higher level, technology becomes an essential requirement in the learning process at school. Therefore preparing students regarding technology is also important.

\section{G. Training}

Training for Physical Education teachers, mainly related to the application of information technology, digital, computers and smartphones are very important to prepare their competence in the industrial revolution era 4.0. There are still many teachers who are not skilled in the use of developing media technology today. They are preoccupied with administrative matters in teaching, and they also concern themselves with other matters that are not related to their duties such as training on how to make athletic, swimming, soccer learning videos and others. Physical Education Teachers need to have a lot of information about internet information sources that can add materials or learning media; For example, teachers know games for children that can stimulate students in exercising, have a healthy lifestyle, and others.

Training can be done by the school itself or in a group of subject teachers. This must be arranged in the form of planned training, programmed, clear and sustainable targets. Through training or group collaboration, each teacher will continue to develop his abilities. For example, every week training is done using smartphones with simple applications or making learning videos that can be used in school activities. The learning media can be done by groups so that the existing media can be monitored together, used together and evaluated together. Every week the plan has been prepared, and there is a clear follow-up plan so that within a year the teachers already have abundant materials and better competencies.

\section{H. Selection of Technology and Learning Methods}

Physical Education teacher competencies in the Industrial Revolution 4.0 era are characterized by the skills of using existing information technology, creative in the choice of technology/application and the right method. Several technologies can be used in Physical Education learning, including:

- Sports games. Many sports games can be accessed for free, both online and offline. Although physically not run by students, it can help students to gain knowledge from certain types of sports.
- Videomaker application. It seems that there are very few teachers who currently cannot record via mobile phones. Almost all mobile products currently offer video recording facilities. This application can be used by their learning process; they are students in exercising. Through this video can be analyzed the shortcomings and advantages. Students are invited together with the results of the recording so that improvements can be made convincingly.

- Communication application. Whatsapp for example as a communication chat application can be used by teachers in building communication relationships with students and parents. Communication between teacher and student is very important. Learning materials can also be shared through this application to facilitate the delivery of material to students.

Some of these are steps that can be pursued to prepare Physical Education teachers in the Industrial Revolution 4.0 era which is characterized by fast information technology, sophisticated digital media, computer intelligence. All have relationships, relationships. Training will be influenced by school capacity, ability before becoming a teacher or experience while studying. Similarly, the condition of students also affects the need for training needed by the teacher. Thus, it cannot be a single factor that must be considered, but all factors.

\section{The Role Of The Supervision In Preparing Teacher Education Teachers In The Industrial Revolution Era 4.0}

Supervision, in this case, must be seen as an effort to help teachers improve their abilities and professionalism, not efforts to find fault with teachers. Thus, the effort to prepare Physical Education teachers in the 4.0 industrial revolution era needs a significant supervision role. For this purpose, the authors propose a conceptual framework for the role of supervision in preparing Physical Education teachers in the Industrial Revolution era 4.0. The concept is as follows:

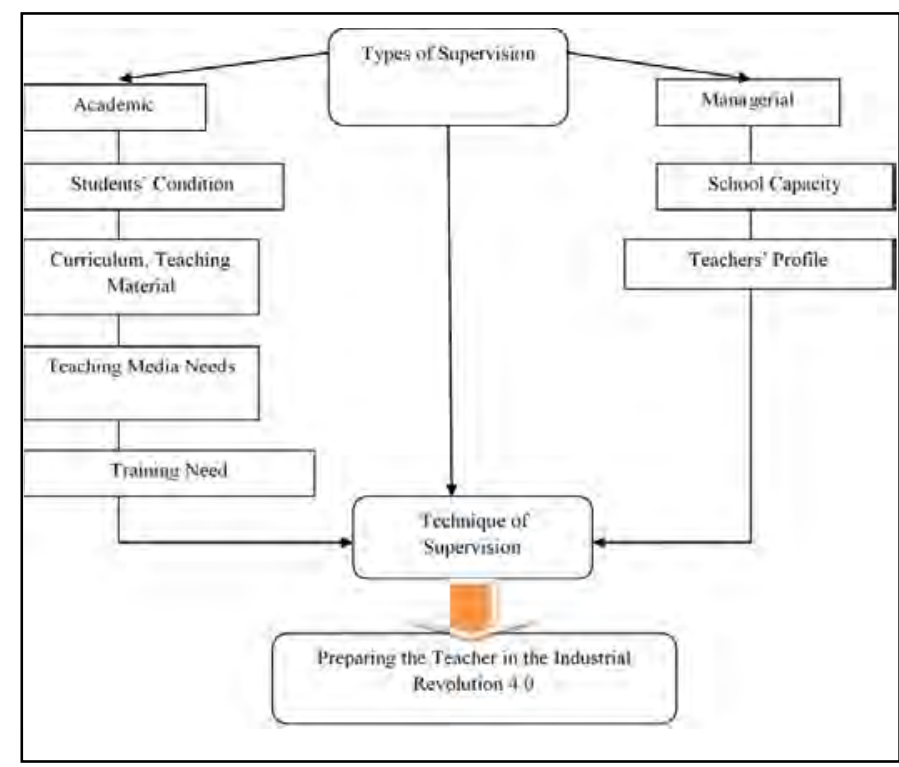

Fig. 2. Preparing of Teacher in the Industrial Revolution 4.0 
The picture above shows that there are two crucial aspects in education supervision, namely academic supervision and managerial supervision. Both of this supervision is needed to prepare Physical Education teachers in the industrial revolution era 4.0. This is related to the conceptual framework for preparing Physical Education teachers themselves which have been discussed in the previous sub-section. Namely, there are aspects of students, teachers, and schools. Therefore, these two supervision needs to be applied.

Academic supervision emphasizes more on matters related to the learning process, which is aimed at knowing the state of students, curriculum and teaching materials, instructional media and appropriate training needs for Physical Education teachers. Through this academic supervision process, it is expected that all necessary information is obtained with sufficient data accuracy so that the preparation process for Physical Education teachers is directed and programmed. For example, not all schools are required students to use tablets or smartphones in the learning process in the classroom. But there are several schools whose students are ready to use these advanced technologies. To find out the condition of students, a supervision process is needed. Thus supervision is not only an evaluation and control effort but has become a process of measuring (needs) or assassination. Through supervision, school policies can be varied, and innovations born to teachers can vary. In essence, there is no uniformity in this matter. This is the essence of the dynamic change of every social change all that can be done through the proper supervision process.

Managerial supervision is carried out with the aim of getting a picture of the school's ability, for example in the budget, school policy, and knowing the profile of Physical Education teachers. About the importance of the profile of Physical Education teachers related to the needs of information technology training in college, it is very important. This can be done managerially. Therefore, the type of supervision carried out is managerial supervision. Managerial supervision is also needed to know and assess the ability of the school budget, the school management policy that has been by the demands of change or not. If the results of managerial supervision result in recommendations not to train teachers and use information technology in the learning process, then the school will not force it. Need to find other solutions that can bridge these needs.

These two provisions are carried out in stages before undertaking technical activities to prepare Physical Education teachers to meet the demands of the industrial revolution era 4.0. The next supervision is also more technical because the implementation can be simultaneously to prepare Physical Education teachers through various activities. Supervision techniques in general also apply to all academic supervision. Some supervision techniques are: a) class visits, b) private talks, c) group discussions, d) teaching demonstrations, e) class visits between teachers, f) curriculum development, g) individual libraries, h) workshops and i) surveys community school [14].

In the use of information technology, applications, digital media, smartphones, and others for the benefit of the Physical Education learning process by teachers, supervisors can carry out various supervision techniques that aim to help teachers better understand and master their tasks, and provide clear direction from each technology choice and media used. Supervisors can visit classes when the teacher applies technology in learning, or discuss with the teacher concerned, or create a group of similar teachers to explain it. The point is during the process of implementing the teacher to adjust the demands of the industrial revolution 4.0, the role of supervision is still needed not only at the initial stage, but during the process and until the end of the evaluation of each activity. The role of supervision is very important in helping Physical Education teachers prepare themselves to enter the industrial revolution era 4.0.

\section{CONCLUSION}

This fourth generation industrial revolution is marked by the emergence of supercomputers and Artificial Intelligence. The challenge of education in the future is how to prepare human resources that will not be replaced by the machine. The world of education is directly influenced by this industrial revolution. How to teach teachers and the style of learning students already rely on the internet. They are looking for sources of information with broad access without being limited by region and time. If the education world is not responsive to this problem, then our education will also stagnate. Inevitably, we must anticipate this dramatic change. We can no longer rely on and be faithful to the system of learning with lecture methods.

Several things must be considered in preparing Physical Education teachers in this 4.0 industrial revolution era, namely: pre-profession or college time, school capacity, student condition. This business cannot rely on just one thing, such as pre-profession or college, but training is also needed. It will all help the teacher to have the competencies needed to determine, choose and apply technology in the process of learning Physical Education in schools.

In this case, the process, education supervision is needed, which is specifically academic and managerial supervision. These two supervisions will help schools understand the real conditions for meeting the needs of teachers and students. Furthermore, supervision of education is still needed during the process of implementing Physical Education teachers who are ready to meet the demands of the industrial revolution 4.0. Supervision will always accompany the preparation process of Physical Education teachers entering the industrial revolution era 4.0 which is very fast, dynamic and advanced technologybased.

\section{REFERENCES}

[1] R. Mengko, "Mengenal Konsep Revolusi Industri 4.0," detik.com, 2018.

[2] C. D. Glickman, S. P. Gordon, and J. M. Ross-Gordon, Supervision and Instructional Leadership: A Developmental Approach, 6th ed. Boston: Ally and Bacon, Inc, 2003.

[3] J. W. Creswell, Educational Research. Boston: Pearson Education, Inc, 2012.

[4] A. Widyantoro, "Tingkat Kreativitas Guru Penjas Dalam Memodifikasi Sarana Dan Prasarana Pembelajaran Penjas Di Sd Negeri Se-Kecamatan Galur Kabupaten Kulon Progo Tahun 2015," Universitas Negeri Yogyakarta, 2015. 
[5] D. Pujianto and B. Insanistyo, "Pemetaan Profil Dan Kompetensi Guru Pendidikan Jasmani Dan Kesehatan Tingkat Sekolah Dasar Di Kota Bengkulu,” J. Pendidik. Jasm. Indones., vol. 10, no. 1, 2014.

[6] D. Dartija, "Kemampuan Guru Pendidikan Jasmani, Olahraga Dan Kesehatan (Health and Recreation Physical) Dalam Menyusun Laporan Penelitian Tindakan Kelas Di SD Negeri Se Kota Banda Aceh,” J. Penjaskesrek, vol. 4, no. 2, 2017.

[7] M. C. Herring, C. R. Edginton, P. L. Geadelmann, and M. K. Chin, "Emerging perspectives on learning and technology in physical education: Policy implications," in Contemporary uses of technology in K-12 physical education: Policy, practice and advocacy, S. Sanders and L. Witherspoon, Eds. Charlotte, NC: Information Age, 2012, pp. 21-53.

[8] A. Gibbone, P. Rukavina, and S. Silverman, "Technology Integration in Secondary Physical Education: Teachers' Attitudes and Practice," J. Educ. Technol. Dev. Exch., vol. 3, no. 1, pp. 27-42, 2010.

[9] Martadi, "Guru bagi Generasi Milenial di Era Revolusi Industri 4.0," girimu.com,
[Online]. http://www.girimu.com/2018/03/08/guru-bagi-generasi-milenial-di-erarevolusi-industri-4-0/. [Accessed: 08-Mar-2018].

[10] M. Monguillot, "La colaboración docente: una forma de vivir, hacer y sentir la docencia.." En Magazine INED 21, 2015. [Online]. Available: http://ined21.com/la-colaboracion-docente-una-forma-de-vivirhacer-ysentir-la-docencia/.

[11] H. S. Gloria, "Resumen del proyecto \#quesepegue," 2012.

[12] A. Casey and B. Jones, "Using Digital Technology to Enhance Student Engagement in Physical Education," Asia-Pacific J. Heal. Sport Phys. Educ., vol. 2, no. 2, 2011.

[13] D. Nagel, "6 Technology Challenges Facing Education," 2013. [Online]. Available: https://thejournal.com/articles/2013/06/04/6-technologychallenges-facing-education.aspx. [Accessed: 06-Apr-2013].

[14] A. Mardhiah and N. Usman, "Peningkatan Profesionalitas Guru Melalui Supervisi Akademik Di SMP Negeri 3 Peusangan Kabupaten Bireuen," J. Adm. Pendidikan, Pascasarj. Univ. Syiah Kuala, vol. 4, no. 2, 2014 